\title{
Olive oil and pomace olive oil processing
}

\author{
By Kostas Antonopoulos, Nick Valet, Dimos Spiratos and George Siragakis*
}

\author{
Quality Assurance Department, Minerva Oleic SA, Shimatari 32009 Viotia, Greece \\ * Corresponding author: Tel: 00306978118047, Fax: 00302262058617, E-mail:gsirag@minerva.com.gr
}

\section{RESUMEN}

\section{Procesado de aceite de oliva y aceite de orujo}

El procesado del aceite de oliva se introdujo en la industria alimentaria a finales del siglo diecinueve y desde entonces se han realizado considerables mejoras. Los pasos de refinación son: decantado, neutralización, decoloración, y desodorización. La monitorización de una refinación efectiva así como el uso de procesos que eliminen una menor proporción de componentes menores del aceite de oliva, tales como polifenoles y tocoferoles, son algunos de los objetivos del proceso. La rigurosa normativa medioambiental y el interés de la industria por introducir mejoras y ahorro de costes han forzado a los fabricantes de equipos a innovar y desarrollar nuevos productos. La eliminación completa de los hidrocarburos aromáticos policíclicos durante el refinado del aceite de orujo y la utilización de los destilados son también áreas importantes de investigación y desarrollo.

PALABRAS-CLAVE: Aceite de oliva - Aceite de orujo Ceras - Componentes menores - Desodorización - Mejores técnicas - Refinación.

\section{SUMMARY}

\section{Olive oil and pomace olive oil processing}

Olive oil processing is introduced in food industry at the end of the nineteenth century and a lot of improvements have been initialized since. The steps for refining are, settling, neutralizing, bleaching and deodorizing. Monitoring of effective refining and the use of processes that remove less minor components of olive oil, like polyphenols and tocopherols are some issues for the process. The stringent environmental requirements and the target of industry for continuous improvements and cost savings, forcing equipment manufacturers to innovations and new products. The complete removal of polycyclic aromatic hydrocarbons during pomace oil process and the utilization of distillates are also important areas for research and development.

KEY-WORDS: Available techniques - Deodorization Minor components - Olive oil - Pomace oil - Refining Waxes

\section{INTRODUCTION}

More than 750 million olive trees are cultivated world wide, the greatest number of which (c. 95\%) being planted in the regions of the Mediterranean. About 3 / 4 of the global olive oil production come from the European Union, while around $97 \%$ of
European production comes from Spain, Italy and Greece. These olive trees produce 2.5 million tones of olive oil and some million tones of edible olives.

The origin of the olive tree is lost in time, coinciding and mingling with the expansion of the Mediterranean civilizations which for centuries governed the destiny of mankind and left their imprint on Western culture.

Olive leaf fossils have been found in Pliocene deposits at Mongardino in Italy. Pieces of wild olive trees and stones have been uncovered in excavations of the Chalcolithic period and the Bronze Age in Spain while the world's earliest olive press was excavated in Crete at the Minoan site of Vathipetro. The existence of the olive tree therefore dates back to the twelfth millennium BC.

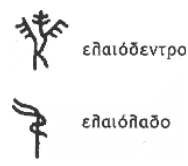

Figure 1

Olive tree and olive oil in Linear B Minoan writing.

The wild olive tree originated in Asia Minor where it is extremely abundant and grows in thick forests. It appears to have spread from Syria to Greece via Anatolia (De Candolle, 1883) although other hypotheses point to lower Egypt, Nubia, Ethiopia, the Atlas Mountains or certain areas of Europe as its source area. Caruso for that reason believed it to be indigenous to the entire Mediterranean Basin and considers Asia Minor to have been the birthplace of the cultivated olive some six millennia ago. The Assyrians and Babylonians were the only ancient civilizations in the area who were not familiar with the olive tree.

In the 16th century BC the Phoenicians started disseminating the olive throughout the Greek isles, later introducing it to the Greek mainland between the 14th and 12th centuries BC where its cultivation increased and gained great importance in the 4th century BC when Solon issued decrees regulating olive planting. The olive tree was the gift of Godness Minerva (Athena) to the Athenians who preferred it rejecting the war-horse which was the gift from God Neptunus (Posidon). 
Olive growing was introduced into Spain during the maritime domination of the Phoenicians (1050 $\mathrm{BC}$ ) but did not develop to a noteworthy extent until the arrival of Scipio (212 BC) and Roman rule (45 BC). After the third Punic War, olives occupied a large stretch of the Baetica valley and spread towards the central and Mediterranean coastal areas of the Iberian Peninsula including Portugal. The Arabs brought their varieties with them to the south of Spain and influenced the spread of cultivation so much that the Spanish words for olive (aceituna), oil (aceite), and wild olive tree (acebuche) and the Portuguese words for olive (azeitona) and for olive oil (azeite), have Arabic roots.

With the discovery of America (1492) olive farming spread beyond its Mediterranean confines. The first olive trees were carried from Seville to the West Indies and later to the American Continent. By 1560 olive groves were being cultivated in Mexico, then later in Peru, California, Chile and Argentina, where one of the plants brought over during the Conquest - the old Arauco olive tree - lives to this day.

In more modern times the olive tree has continued to spread outside the Mediterranean and today is farmed in places as far removed from its origins as southern Africa, Australia, Japan and China.

\section{OLIVE OIL PROCESSING}

The history of olive oil processing is also very old. According to Pedanius Dioskorides, a Greek physician who lived 2100 years ago, decoloration of olive oil was a common process for the ancient Greeks.

A traditional method of making soap was the total saponofication of the inferior quality olive oil, using Potasium Hydroxide.

In 1900, an American chemist David Wesson, introduces a new method for deodorizing cottonseed oil. Wesson's vacuum and high temperature process will revolutionize the cooking oil industry and will largely overcome the prejudice against cottonseed oil, which until then, has been deodorized only by heating it with a steam coil and blowing live steam through it at atmospheric pressure.

This method was the base for the olive oil industry. The total saponofication for the production of soap was replaced by a selective saponofication using Caustic Soda which saponofies under special contitions only the free fatty acids of the oil. The neutral oil had an even more bad odour from the raw material. David Wesson's method helped to deodorize this olive oil and after mixing with an extra virgin one to be offered to the consumer as "classic" olive oil. Wesson gave his name also to the wesson loss analytical method for estimation of refining loses in pomace oil.
The fact that only the minority of olive oil production is extra virgin olive oil and that olive oil consuming is raising, makes olive oil refining a very important sector of food industry.

Lampante olive oil reduce a lot of beneficial constitutes like extra virgin olive oil and a process to make this oil edible was the target of olive oil refining industry.

\section{SETTLING OF OLIVE OIL}

Vegetable oil indusrty begins with degumming whitch is the first stage of refining.

In olive oil industry this process is replaced by settling because of small amounts of phosphatides in raw material.In fact the removal of gums take place during neutrilization stage by adding phosphoric or citric acid in order to remove phosphitides jointly with soaps.

Settling is an important stage in olive oil refining as it is necessary to avoid cloudiness and sentiment in the bottled olive oil.

Exept of removing phosphatides, settling removes moisture, impurities and some waxes.

Table 1

Settled and semisettled lampante Olive Oil $(50 \%$ is the middle of the tank and $2 \%$ is the botom

\begin{tabular}{lccccc}
\hline \multirow{2}{*}{ Raw material } & \multicolumn{2}{c}{$\mathbf{1}$ week settled } & & \multicolumn{2}{c}{$\mathbf{4}$ weeks settled } \\
\cline { 2 - 3 } \cline { 5 - 6 } & $\mathbf{5 0 \%}$ & $\mathbf{2 \%}$ & & $\mathbf{5 0} \%$ & $\mathbf{2 \%}$ \\
\hline Moisture & 0,5 & 0,6 & & 0,2 & 1,5 \\
Phosphatides & 8,8 & 10 & & 3,3 & 18,8 \\
Waxes & 250 & 260 & & 240 & 380 \\
Total Sterols & 1500 & 1505 & & 1490 & 1700 \\
Free Fatty Acids & 6,1 & 6,2 & & 6 & 6,9 \\
\hline
\end{tabular}

The main factors that effect for an effective settling are:

- The time: A time period of four weeks minimum is the demand depending on moisture, impurities, phosphatides and freshness of raw material.

- The temperature: A constant temperature 20$25 \mathrm{C}^{\circ}$ has the best results in settling

- The Tank Shape: A reverse cone is the best shape for the oil settling

Crude (Lampante) olive oil after settling, contains different types of undesirable substances: 1.0 to $10.0 \%$ free fatty acids (ffa), phosphatides, traces of metals, colouring components and water. The removal of $\mathrm{ffa}(<0.1 \% \mathrm{ffa}$ in refined oil) can be achieved either by caustic neutralisation in a chemical refinery or by distillation in a physical refinery. 
The chemical neutralisation consists of an addition of caustic soda (at $75-110^{\circ} \mathrm{C}$ ) to saponify the free fatty acids in order to precipitate soaps in the heavy aqueous phase and remove the heavy phase, called soapstock, by using gravity or centrifugation. Removal of non hydratable gums and phosphatide acids can be integrated in this process using a proceeding acidification step, i.e. using phosphoric acid or citric acid.

In a soapstock splitting plant, the fatty acid soaps react with sulphuric acid to form fatty acids back again. The process can either be continuous or discontinuous. The reaction medium is heated up to $70-100^{\circ} \mathrm{C}$ in order to increase the speed of the reaction and to improve the separation of the upper oil phase from the lower aqueous phase. Between the aqueous phase and the fatty acids, an intermediate layer of phosphatides can be formed, depending on the amount of phosphatides still present in the crude oil.

\section{NEAUTRALIZING}

The objectives of the neutralization step are the removal of free fatty acids and also the elimination of various impurities and contaminants.

Most contaminants like pesticides, aromatic hydrocarbons and metals are eliminated by caustic soda during neutralization stage. Phosphatides and chlorophyll pigments are also removed after neutralization stage.

These results must be accomplished with minimum neutral oil losses, which occur due to emulsification, occlusion in the soapstock and saponification.

Normally, the theoretically calculated amount of lye is not sufficient for obtaining an optimum result. Firstly, the oil does not always become neutral with the stoichiometric quantity of lye and, secondly, the losses in the neutralization stage depend highly on the excess the type and the concentration of the lye.

The type of the lye could be $\mathrm{Na}_{2} \mathrm{CO}_{3}+\mathrm{NaOH}$, $\mathrm{NaOH}, \mathrm{KOH}$ or $\mathrm{Ca}(\mathrm{OH})_{2}$

For a clear understanding of the factors influencing the yield, it should be noted that in the neutralization of crude olive oil four different kinds of losses occur:

- The free fatty acids

- The colouring matters and other impurities, which are removed in the neutralization

- The saponification losses, which arise through saponification

- The neutral oil lost in the soapstock

The refining factor for neutralization is the quotient of the neutralizing losses and the FFA as per cent in the crude oil without any saponification would then be.

$\mathrm{R}=$ losses/FFA
Table 2

Quality parameters after Olive oil Neutralization

\begin{tabular}{lccc}
\hline Parameter & Crude & Neutral & $\%$ loss \\
\hline FFA \% & 7 & 0,08 & $98,9 \%$ \\
Moisture \% & 0,5 & 0,1 & $75,0 \%$ \\
Phosphatides \% & 0,38 & 0,07 & $81,6 \%$ \\
Fe (ppm) & 37 & 4 & $89,2 \%$ \\
Cu (ppm) & 4,1 & 3,6 & $12,2 \%$ \\
Peroxides meq/kg & 12,5 & 12,8 & - \\
Total sterols (ppm) & 1700 & 1550 & $9,5 \%$ \\
\hline
\end{tabular}

\section{BLEACHING}

Bleaching is a process developed to remove from the oil the natural pigments, compromised by bad preservation and responsible of unpleasant colorings, metals (iron or cooper) and residual soaps.

In order to remove the resins from the oils are warmed at the $75^{\circ}-95^{\circ} \mathrm{C}$ and hot water is injected on the surface, with a simultaneous shaking of the oil's mass. For a higher performance, citric acid is added at a specific ratio.

The oil is mixed with 0,1 to $3 \%$ of bleaching earth or activated carbon, which have a high absorbing capacity.

Bleaching Color of an oil is resultened from the lipochroms specific to each oil. The most common natural coloring compounds are alpha and beta carotene, xantophyll and chlorophyll in olive oil. However, in addition to these natural compounds, crude oils obtained from seeds of low quality and stored under high temperature, moisture and oxygen contains coloring compounds which are formed by the oxidative reactions and darkens oil. Consequently, these kinds of oils are hard to bleach.

If olive oils contain unacceptable levels of PAH's (polycyclic aromatic hydrocarbons), activated carbon is added to absorb and eliminate the PAH's. The used activated carbon is separated by filtration and disposed of in a suitable way outside of the food and feed sector.

The main benefit with the bleaching stage is the removal of soap, pesticides and any other organic contaminant (PCBs, PAH, Halogenates) as the bleaching earth strongly absorbs these compounds. The inorganic compounds like metals are also eliminated by bleaching specially using silica based bleaching and absorbing earth like trisyl. The rise of K270 value that can be doubled or even more is the main problem with this stage. Special conditions and precautions should be taken in order to keep the K270 values as low as possible.

The factors from that it depends the rise of K270 in bleaching stage are:

1) Initial K270 of neutral olive oil before bleaching 
2) The oxidant situation of oil before his treatment as it is also proved by the value of K232 (greater price of K232 in the initial oil indicates a trend for increasing the K270 value during bleaching)

3) The conditions of process (temperature, time, rythm and type of steering, percentage and type of bleaching earth (activated or not).

\section{DEODORIZING}

Deodorizing is the final treatment step in the refining process from crude oil to finished oil. The pre-treated oil is heated up to deodorising temperature $\left(180-270{ }^{\circ} \mathrm{C}\right)$ via heat exchange and indirect steam. To prevent oxidation of the oil the atmosphere in the deodorising equipment is at almost absolute vacuum i.e. $0.2-0.4$ mbar. At the given vacuum and temperature conditions stripping steam provides the driving force and the carrier for removing volatile components from the feedstock.

A comon device for the refining of olive oil, in great olive oil refining plants is a scrubber.

The vapours from the deodoriser vessel contain air, water vapour, fatty acids and other volatiles. Prior to entering the vacuum equipment the vapours pass a scrubber. A scrubbing liquid is sprayed in the vapour stream. Fatty acids and volatiles partly condense on the scrubbing droplets or alternatively on packing material. Since the scrubber is at the same vacuum as the deodoriser water vapour will not condense. The scrubber is equipped with a dedicated scrubbing loop, a heat exchanger to remove the heat of condensation, possibly some packing material and a demister pad.

The pre-cleaned vapour stream now enters the booster steam ejector of the multi stage vacuum system. The steam jet is a thermo compressor and hence the vapour pressure increases up to $30-50$ mbars. In a classical designed vacuum system the vapours are then condensed in an open barometric condenser. The water vapour coming from stripping steam and motive steam are condensed and a tremendous reduction in volume is achieved. This contributes to maintain the vacuum at the specified levels. Non-condensable components from the barometric main condenser are removed by a deaerating system comprising of one or more small intermediate condensers and one or more small steam ejectors. The condensers also use cooling water: $10-15 \%$ of the cooling water flow through the main condenser. The function of 1 or 2 steam jets may be replaced by the application of a liquid ring vacuum pump.

Cooling system is critical for cost savings and environmental aspects. Basic examples of cooling systems applied in oils and fats refining for vacuum generation in deodorisers are:

Once through cooling water system: The cooling water is surface water that is returned into the environment after passing a fat trap. The presence of fatty material in the cooling water is very limited. The total energy requirements for the system are low.

Alkaline loop system: The cooling water is circulated in a closed loop system. The closed loop requires a set of heat exchangers and produces a bleed flow equal to the amount of stripping steam. A caustic dosing system may be necessary to reduce fouling problems. The introduction of a loop system increases the steam consumption for generating the same vacuum.

Alkaline loop system with a chiller unit: The cooling water loop operates at a lower temperature level due to the loop system being cooled by a chiller unit. The introduction of a chilled loop system reduces the amount of driving steam needed but the chiller unit requires extra electricity and cooling water.

Dry condensing system: Condensable components present in deodorising vapours after scrubbing are removed from the vapour stream by condensation on a heat exchanger surface at approx. $-30{ }^{\circ} \mathrm{C}$. The chiller unit requires extra electricity and cooling water. Ammonia is used as refrigerant.

The energy requirements for the deodorising step in a refinery involve more then $50 \%$ of the refinery total energy consumption. Closed loop alternatives therefore result into 10-20\% higher Specific Energy Consumption figures (SEC in MJ/tonne).

The systems described are compared on the basis of generating a moderate vacuum of approx. 4 mbar in the following table:

Table 3

Main consumptions dyring olive oil refining

\begin{tabular}{|c|c|c|c|c|c|c|}
\hline $\begin{array}{l}\text { Cooling systems for } \\
\text { vacuum generation }\end{array}$ & steam & electricity & $\begin{array}{l}\text { total primary } \\
\text { energy input }\end{array}$ & effluent & $\begin{array}{l}\text { Investment } \\
\text { costs }\end{array}$ & $\begin{array}{c}\text { System } \\
\text { complexity }\end{array}$ \\
\hline Once through system & - & ++ & ++ & -- & ++ & ++ \\
\hline Alkaline loop & -- & + & $-/+$ & - & + & + \\
\hline Alkaline loop with chiller & + & - & - & + & - & - \\
\hline Dry Condensing & ++ & -- & - & ++ & -- & -- \\
\hline
\end{tabular}

$+(++)=($ most $)$ favourable and $-(--)=($ most $)$ unfavourable

Note: The total primary energy input for the specified vacuum system is the sum of the amount of energy needed in the plant for generating steam and the energy input in the external power plant to produce the electricity needed. 


\section{MONITORING EFFECTIVE REFINING}

The developments in chemometrics have made possible the automatic analysis of oils and fats. Fat, moisture, fatty acids, UV constants and other parameters appear on the screen of the automatic analyzers within seconds. NIR Spectroscopy provides one of the most promising and welldocumented method. It is simple, non-destructive and rapid. NIR photometers can be used on the production floor since they are able to provide "realtime" results. An example refers to the monitoring of olive oil production using NIR automatic analysers. This monitoring could be either automatically on line, or by the operators as it does not demand special training.

Table 4

The parameters that can be meausured by NIR for effective refining monitoring

\begin{tabular}{lcc}
\hline Parameter & Accuracy & Units \\
\hline FFA & 0.11 & $\%$ \\
FFA < 2\% & 0.05 & $\%$ \\
Peroxide value & 1.66 & $\mathrm{meq} / \mathrm{kg}$ \\
Polyphenols & 57 & $\mathrm{mg} \mathrm{caff} / \mathrm{kg}$ \\
Rancidity & 0.97 & Hours \\
Palmitic acid & 0.57 & $\%$ \\
Pamitoleic acid & 0.12 & $\%$ \\
Stearic acid & 0.3 & $\%$ \\
Oleic acid & 0.56 & $\%$ \\
Linoleic acid & 0.21 & $\%$ \\
Linolenic acid & 0.07 & $\%$ \\
Chlorophyl & 0.47 & $\mathrm{mg} / \mathrm{kg}$ \\
UV232 & 0.18 & \\
UV270 & 0.022 & \\
\hline
\end{tabular}

The principle of the method is the calibration using the Artificial Neural Network. Three parameters are taken for the calibration: absorbance, bandpass response and wavelength response.

\section{PHYSICAL VERSUS CHEMICAL REFINING}

It is possible to remove all the free fatty acids (ffa) that is present in the oil in the deodoriser. When doing so the neutralisation process can be skipped. This is generally done, except in the above mentioned cases of dependency of raw material and products when the in coming oil is rich in $\mathrm{ffa}$ $(>2 \%)$ and low in phospholipids (approx. less then $10 \mathrm{ppm}$ ). The scrubber system after the deodoriser will have to remove a much higher amount of ffa than in case of normal deodorisation.

Physical refining requires oil with low phospholipids content. The crude olive oil has low phosphatides content (below $150 \mathrm{ppm}$ ) so is ideal for physical refining. The main advantage of physical refining is the less waste disposal.



Figure 2

DeSmet Deodorizer

Table 5

Sterol and waxes changes after olive oil refining

\begin{tabular}{|c|c|c|c|c|}
\hline & $\begin{array}{c}\text { Lampante } \\
1\end{array}$ & $\begin{array}{c}\text { Lampante } \\
2\end{array}$ & $\begin{array}{l}\text { Refined } \\
\quad 2\end{array}$ & $\begin{array}{c}\text { Refined } \\
1\end{array}$ \\
\hline Erythrodiol + Uvaol, \% & 2,7 & 3,6 & 3,4 & 3,6 \\
\hline Cholesterol, \% & 0,2 & 0,23 & 0,3 & 0,36 \\
\hline Brassicasterol, \% & 0,05 & 0,07 & 0,05 & 0,04 \\
\hline Campesterol, \% & 3,1 & 3,02 & 2,8 & 3,6 \\
\hline Stigmasterol, \% & 1,4 & 2,06 & 1,5 & 1,9 \\
\hline B-sitosterol, \% & 93,8 & 94,1 & 94 & 93,22 \\
\hline$\delta$-7-stigmastenol, \% & 0,32 & 0,29 & 0,35 & 0,3 \\
\hline Total sterols, $(\mathrm{mg} / \mathrm{kg})$ & 1450 & 1490 & 1290 & 1150 \\
\hline Waxes & 370 & 245 & 296 & 385 \\
\hline FFA & 9,5 & 6,1 & 0,03 & 0,03 \\
\hline k270 & 0,52 & 0,38 & 0,77 & 1,06 \\
\hline
\end{tabular}


Table 6

Sterol fraction changes after olive pomace oil, neutrilizing and bleaching, refining

\begin{tabular}{|c|c|c|c|}
\hline & $\begin{array}{l}\text { Crude } \\
\text { Pomace }\end{array}$ & $\begin{array}{l}\text { Neutralized } \\
\& \text { Bleached }\end{array}$ & Deodorized \\
\hline $\begin{array}{l}\text { Erythrodiol + } \\
\text { Uvaol, \% }\end{array}$ & 30 & 35,8 & 37,8 \\
\hline Cholesterol, \% & 0,2 & 0,1 & 0,1 \\
\hline Brassicasterol, \% & 0,1 & 0,1 & 0,1 \\
\hline Campesterol, \% & 3,9 & 4 & 3,9 \\
\hline Stigmasterol, \% & 2 & 1,7 & 1,6 \\
\hline B-sitosterol, \% & 93,15 & 93,23 & 93,31 \\
\hline$\delta$-7-stigmastenol, $\%$ & 0,23 & 0,4 & 0,4 \\
\hline Total sterols, (mg/kg) & 3350 & 2118 & 1683 \\
\hline
\end{tabular}

The rising of wax content during refining is a very serious problem especially in areas where the lampante olive oil has usually high wax content.

A mathematical algorithm for the prediction of wax rising is provided after a lot of measurements. FFA and the Factor $\mathrm{K}$ (specific for each process) are the parameters needed for this calculation.

$$
\text { Cwaxref }=(\text { Cwaxin/ }(1-F F A(\%) / 100)){ }^{*} k
$$

Table 7

Waxes changes after olive oil refining and factor $\mathrm{K}$ for estimating rising

\begin{tabular}{cccc}
\hline $\begin{array}{c}\text { FFA } \\
\text { Lampante }\end{array}$ & Waxes & Factor k & $\begin{array}{c}\text { Waxes after } \\
\text { refining }\end{array}$ \\
\hline 6,6 & 245 & $\mathbf{1 , 0 9}$ & 286 \\
9,3 & 370 & $\mathbf{1 , 1 0}$ & 449 \\
6,1 & 260 & $\mathbf{1 , 1 1}$ & 308 \\
7,2 & 369 & $\mathbf{1 , 0 7}$ & 426 \\
3,5 & 330 & $\mathbf{1 , 0 9}$ & 374 \\
7,4 & 185 & $\mathbf{1 , 2 0}$ & 240 \\
7,8 & 333 & $\mathbf{1 , 1 0}$ & 395 \\
Factor K average & & $\mathbf{1 , 0 9}$ & \\
Stand. Deviation & & $\mathbf{0 , 4 2}$ & \\
\hline
\end{tabular}

\section{QUALITY PARAMETERS AFFECTED BY REFINING}

Significant changes produced by the action of the independent variables (temperature, flow of stripping gas, thickness of oil layer in the deodorizer, and length of the process) on different quality parameters of olive oil deodorized and/or physically refined in continuous and discontinuous process. The changes affect the unsaturated fatty acids (elaidization), the contents of 3,5stigmastadiene (dehydrated beta sitosterol) and saturated fatty acid in the beta position. The content in trans fatty acids of the deodorized oils depends indirectly on the four variables, and the trans content of 18:2 and 18:3 may exceed -depending on raw material- the permitted limit when the temperature is above $250{ }^{\circ} \mathrm{C}$ and the residence times are long. The same occurs with the content of saturated fatty acids in beta position of triglyceride and 3,5-stigmastadiene. It is suggested, the olive oil to be deodorized at lower temperature, with longer residence time and greater energy spending. As the different olive oils have different initial characteristics, it is of interest to establish criteria able to forecast whether particular oil could be refined under pre-set conditions.

The triterpene alcohol fraction in refined oils by alkali and physical refining process is also changing. A D7 compound occure in olive oils during refining. This compound can be identified by gas chromatography - mass spectrometry (GC-MS) as being 24-methyl-5D-lanosta-7,24-dien-3D-ol. It is a 24-methylencycloartanol isomer produced during the refining process by the opening of the 9,19 cyclopropane ring with formation of a double bond in the D7 position and the translocation of a double bond in the side chain from the 24-28 to the 24-25 position.

Sterols in olive oil are mostly (approx. $75 \%$ ) in the free form and only $25 \%$ are in esterifired form, this composition is beneficial if deodorization is to be used for sterol removal. This is due the fact that free sterols are more volatile than esterified form. The used process conditions and process additives have an impact to the sterol removal. Only small amounts of sterols is removed in the early refining steps neutralization and bleaching but the main sterol removal is occured in the deodorization step. This is due sterols relatively high vapour pressure at elevated temperatures and high vacuum. Dewaxing process might also have a small sterol reduction effect because low temperature is used and high melting point serols might be crystallize into the solid phase.Anyways the main process step for sterols removal is deodorization, and the higher temperature and vacuum is used, the more sterols are removed. Tocopherols are also increasingly stripped off into the deodorization distillate.

\section{BAT FOR ENVIRONMENTAL FRIENDLY REFINING}

The Directive EC/96/61 intends to introduce an integrated approach for the prevention and control of the pollution arising from the industrial activities. For Olive Oil or Olive Pomace oil Refining the plants that process more than 300 tones per day have to implement, by the end of October 2007. The introduction of the Integrated Pollution Prevention and Control (IPPC Directive) in the European Union aims at the improvement and upgrading of the environmental protection. Prevention measures are specified, or where that is not practicable, measures that reduce emissions to air, land and water from the industrial activities are proposed. In 
this manner, a high level of integrated environmental protection can be archived. In the last meeting of Working Group FDM (Seville March 2005), four Best Available Techniques (BATs) for olive oil refining industry were suggested.

- Removal and recovery of free fatty acids in olive oil chemical refining.

- Waste minimisation in vegetable oil degumming, using citric acid instead of phosphoric acid during neutralisation stage.

The double scrubber arrangement results in an improved scrubbing efficiency of the deodoriser vapours. The second scrubber operates at a higher pressure and because of the motive steam addition via the booster steam jet the partial pressure of the volatiles is reduced. These two factors provide the basis for further condensation. The scrubbing efficiency of the first scrubber is well above $90 \%$ when the feedstock is chemically refined. This pretreatment step accomplishes initial removal of the bulk of the fatty acids. The second scrubber adds another $2-5 \%$ to the overall scrubbing efficiency. The scrubber efficiency is related to the input of fatty acids with the deodoriser feedstock.

The multi stage vacuum system design based on steam ejectors and open condensers with direct cooling water proves to have the lowest energy requirement for generating the desired vacuum based on the consumption of electricity and steam. However this system produces a cooling water flow with increased COD levels. The increase in COD level may vary from $50-150 \mathrm{mg} / \mathrm{l}$ depending on cooling water flow and the quality of the deodoriser feedstock. The double scrubber arrangement results into lower increase of COD levels: $40-100$ $\mathrm{mg} / \mathrm{l}$. Depending on local conditions the double scrubber arrangement is considered as best available technique recognising the relatively low energy consumption and the economic aspects.
The double scrubber arrangement combined with an open multi stage vacuum system has no heat exchangers. Hence there are no problems with heat exchanger fouling and related poor heat transfer issues. Process stability is at a high level due to the simplicity of the system lay out.

$$
\begin{array}{ll}
\text { Steam consumption: } & 50-100 \mathrm{~kg} / \text { tonne oil } \\
\text { Electricity: } & 2-5 \mathrm{kWh} \text { per tonne oil }
\end{array}
$$

\section{Single scrubber in combination with Dry Condensing system}

Dry Condensing systems (also called lce Condensing systems) are placed between the scrubber and the de-aerating system. The scrubber removes the major part of the free fatty acids (ffa). The DC system will take out the remaining part of the $\mathrm{ffa}$ and the stripping steam that was used to drive out the ffa. The steam and ffa are condensed on the coils in the DC system at temperatures as low as $-30^{\circ} \mathrm{C}$. The low temperature is generated by the mechanical compression of ammonia and evaporating it in the coils afterwards. Only noncondensable will pass the scrubber and the DC system to the vacuum system. Since more than $95 \%$ of all the condensable vapours are removed by the DC system the vacuum system can be much smaller.

\section{Polymeric and Oxidized Triaglycerol Content of crude and refined olive oil}

Information on the polymeric and oxidized triacyglycerol content of crude and refined olive oil is very important as there are only a few references. The polar fraction of oils and fats is a very heterogeneous and complex mixture consisting of different compounds like, FFA, mono and diacyglycerols and oxidized dimeric and polymeric triacyglycerols.



Figure 3

Second stage scrubber for better environmental data (Fediol) 
Polymeric triacyglycerols are mostly dimers. Olive oil refining always involves the formation of small amounts of polymeric triacyglycerols. The absence of dimeric triacyglycerols in virgin olive oils can be used in combination with other methods as a parameter to rule out the possibility of adulteration with refined olive oil.

Table 8

Polar Compound content of crude and refined olive oil, corn and sunflower oil

\begin{tabular}{lcccc}
\hline & Total & TGP & OxTGP & DGL \\
\hline Olive Oil crude & 6,5 & 0,3 & 2,4 & 2,3 \\
Olive Oil refined & 6,1 & 1,5 & 2,9 & 2,5 \\
Corn Oil & 5,2 & 0,2 & 1,0 & 2,2 \\
Corn Oil & 4,9 & 1,8 & 1,5 & 2,8 \\
Sunflower Oil & 4,2 & 0,3 & 2,2 & 1,2 \\
Sunflower Oil & 4,1 & 0,7 & 2,9 & 1,4 \\
\hline
\end{tabular}

\section{POMACE OIL REFINING}

Olive pomace refining is a very promising activity as the annual production and comsumption of Olive pomace oil is increased during last years.

Special problems could occur because of the quality of raw material which can be produced as a by product either after a two phases olive oil production or after a three phases one. In the first case because of the moisture and the aditional drying step Polyciclic Aromatic Hydrocarbons may occur and that makes more demanding the process contitions and the quality of active carbon and bleaching earth.

The water in two phases pomace is $60-80 \%$ and that tranfers the problem to the pomace oil extraction. PAH are produced (benzo (a) pyrene till $0,5 \mathrm{ppm}$ ) and that demands more active carbon. During deodorization not all PAH air emisions are captured in barometric water. Aditional active carbon is demanded (even 1\% more) that causes more loses and solid wastes.

In the DG ( SANCO)/8603/2002 Report for the assesment of controls on PAH contamination, refers in paragraph 5 ( Public health) that: Significant levels of $\mathrm{PAH}$ have been found in sunflower, grapeseed and pomace oils derived from olives. Three phases pomace has $30-40 \%$ water and two phases pomace $70-80 \%$. The second is likely to generate higher levels of PAH. Norit SA (active carbon producer) suggests $0,1 \%$ active carbon for each $8 p p b$ benzo(a) pyrene in crude pomace oil. An acceptable range for benzo (a) pyrene in crude pomace oil is $5-30 \mathrm{ppb}$. There is a new European Regulation (208/2005) of 4th February 2005, witch sets limits (2ppb) for all the edible oils and fats. The regulation is applicable from April 2005
Role of raw material (volatiles, residual solvent, soap)

Besides $\mathrm{PAH}$, volatile matter and impurities are also affect the refining process of pomace oil. An amount of residual hexane or other similar solvent greater than $0,1 \%$ may cause difficulties to achieve the required by the processor vacuum and to have insufficient deodorization.

The use of banned solvents like Carbon Disulfite could be avoided by using the Sulfur Test for monitoring the quality of raw material. Soap content is also important as a great amount of "dirty soap" could create problems during dewaxing stage.

\section{Effective removal of Polycyclic Aromatic Hydrocarbons}

The new European Union's Regulation 208/2005, forces the producers to a more strict monitoring of $\mathrm{PAH}$ as there is the limitation of $2 \mathrm{ppb}$ of benzopyrene, not only for pomace oil but for all kinds of olive oils also.

$\mathrm{PAH}$ performs during drying stage before processing or because of environment as virgin or lampante olive oils some times have significant amounts of PAH.

The chemical structure of $\mathrm{PAH}$ is organic compounds with 2 or more benzene rings. Light $\mathrm{PAH}$ have less than 4 rings (Anthracene, Chrysene) and Heavy PAH have more than 4 rings (Benzo (a) pyrene, etc).

Refined oil specifications are:

Total PAH: Max. 25 ppb

Heavy PAH: Max. 5 ppb and each one max 2ppb.

The use of active carbon is the only way to reduce the $\mathrm{PAH}$ content and the active carbon manufactures have set algorithms to calculate the needed active carbon to have a final product according to the low. As the prices of active carbon are pretty high and the losses (the mass of active carbon use the same quantity of oil you loose) are signifficant, a monitoring system for the $\mathrm{PAH}$ content of raw material and final product sould be established.

Table 9

Relative toxicity equivalent factors (TEF) for PAH

\begin{tabular}{lcc}
\hline Compound & TEF & Class \\
\hline Dibenz(a,h)anthracene & 5.0 & Heavy \\
Benzo(a)pyrene & 1.0 & Heavy \\
Benz(a)anthracene & 0.1 & Light \\
Anthracene & 0.01 & Light \\
Naphtalene & 0.001 & Light \\
Pyrene & 0.001 & Light \\
\hline
\end{tabular}


Table 10

Valuable minor components in crude edible oils (ppm)

\begin{tabular}{lccc}
\hline Oil & Tocopherol & Sterols & $\begin{array}{c}\text { Total } \\
\text { Unsaps }\end{array}$ \\
\hline Soybean & 1400 & 4000 & 12000 \\
Palm & 600 & 300 & 4000 \\
Sunflower & 700 & 4000 & 7000 \\
Rapeseed & 700 & 6000 & 9000 \\
Corn & 1400 & 10000 & 20000 \\
Coconut & 50 & 1000 & 4000 \\
Olive oil & 250 & 1500 & 10000 \\
Olive pomace oil & 290 & 3500 & 25000 \\
\hline
\end{tabular}

Table 11

PAH in Greek olive oils before processing

\begin{tabular}{lcccccc}
\hline PAHs & LOD & LOQ & Min & Max & Mean $\begin{array}{c}\text { Rec \% } \\
\text { at Level } \\
5 p p b\end{array}$ \\
\hline Phenanthrene & 0,34 & 1,02 & 7,52 & 89,70 & 39,04 & 116,4 \\
Anthracene & 0,08 & 0,25 & 0,64 & 15,17 & 5,58 & 117,3 \\
Fluoranthene & 0,21 & 0,62 & 0,83 & 29,03 & 8,80 & 96,0 \\
Pyrene & 0,02 & 0,07 & 2,12 & 34,24 & 10,06 & 71,6 \\
B(a)anthracene & 0,02 & 0,05 & 0,00 & 7,09 & 0,65 & 96,3 \\
Chrysene & 0,11 & 0,33 & 0,45 & 13,13 & 2,31 & 99,5 \\
B(b)fluoranthene & 0,09 & 0,26 & 0,00 & 5,66 & 0,56 & 102,1 \\
B(k)fluoranthene & 0,01 & 0,02 & 0,00 & 2,86 & 0,25 & 100,9 \\
B(a)pyrene & 0,05 & 0,16 & 0,00 & 8,23 & 0,54 & 105,9 \\
DB(a,h)anthracene & 0,02 & 0,06 & 0,07 & 1,22 & 0,24 & 99,0 \\
B(g,h,i)perylene & 0,01 & 0,02 & 0,08 & 3,89 & 0,49 & 80,8 \\
I(1,2,3-cd)pyrene & 0,11 & 0,33 & 0,00 & 2,36 & 0,68 & 82,2 \\
Sum Light & & & 14,15 & 181,39 & 66,44 & \\
Sum Heavy & & & 0,00 & 20,25 & 1,93 & \\
Sum Limit & & & 0,18 & 27,34 & 2,58 & \\
Sum & & & 14,45 & 201,63 & 68,36 & \\
& & & & & & \\
& & & & & & \\
& & & & & & \\
& 0,03 &
\end{tabular}

Table 12

PAH Monitoring (EPA, EU, EFSA)

\begin{tabular}{ccc} 
EPA & $\begin{array}{c}\text { European } \\
\text { Union } \\
\text { monitoring }\end{array}$ & $\begin{array}{c}\text { Carcinogenic } \\
\text { according } \\
\text { Legislation }\end{array}$ \\
\hline
\end{tabular}

LIGHT:

\section{Acenapthylene}

Fluorene

Acenaphthene

Napthalene

Phenanthrene

Anthracene

Fluranthene

Pyrene

Benzo (a) anthracene

Chrysene

Methyl Chrysene
HEAVY:

Cyclopentane(c,d)pyrene

Benzo(j)fluranthene

Benzo (e)pyrene

Benzo(b)fluranthene

Benzo(k)fluranthene

B(a)pyrene

$\mathrm{DB}(\mathrm{a}, \mathrm{h})$ anthracene

$\mathrm{B}(\mathrm{g}, \mathrm{h}, \mathrm{i})$ perylene

$\mathrm{I}(1,2,3-\mathrm{cd})$ pyrene

Dibenzo (a,l)pyrene

Dibenzo (a,e)pyrene

Dibenzo (a,i)pyrene

Dibenzo (a,h)pyrene

\section{SPECIAL CONTITIONS FOR} TOCOPHEROLS \& POLYPHENOLS<smiles>[R]c1c([R])c2c(c([R])c1O)CC[C@@](C)(CCC[C@H](C)CCC[C@H](C)CCCC(C)C)O2</smiles>

Figure 4

Tocopherol structure

Polyphenols and Tocopherols are the most important natural antioxidants in olive oil and in several vegetable oils.

Polyphenols are complicated glycosides, which are hydrolyzed and produce simple phenols, mainly tyrosol and hydroxytyrosol. They are produced mainly in the olive fruit and leaves and are part of the polar compounds in olive oil.

Olive oil contains:

a. Phenolic acids (they contain $-\mathrm{OH}$ - and $-\mathrm{COOH}-$, joined with a benzoic ring).

Anthokyanes +Flavons $\rightarrow$ (hydrolysis) simple phenolic acids (kafeic and prokatechic)

Other phenolic acids 3,4,-dimethoxy-4hydroxybenzoic acid, o-cumaric acid, pcumaric acid, p-hydroxybenzoic acid.

b. Phenols and polyphenols

Main phenols: tyrosol (participates per $40 \%$ in the phenolic part), hydroxityrosol the vast volume of phenolic matter and the highly protective compound with antioxidant activity. Although they should not be, they are categorized in the unsaponifiable matter.

The traditional aproach for quality parameters was the aim of zero peroxide value, very law FFA, very light colour, bland taste and as many hours as possible in Rancimat test.

The new aproach is to keep as more antioxidants as posible. Three process contitions 
Table 13

Polyphenols and tocopherols after refining of olive, corn and sunflower oil

\begin{tabular}{|c|c|c|c|c|c|}
\hline & $\begin{array}{l}\text { Process } \\
\text { Contitions } \\
\text { P, 3mbar, T }\end{array}$ & $\begin{array}{c}\text { Total } \\
\text { Polyphenols }\end{array}$ & $\begin{array}{l}\text { ALPHA- } \\
\text { TOCOPHEROL } \\
\text { ppm }\end{array}$ & $\begin{array}{c}\text { BETA+GAMMA } \\
\text { TOCOPHEROLS } \\
\text { ppm }\end{array}$ & $\begin{array}{c}\text { DELTA } \\
\text { TOCOPHEROL } \\
\text { ppm }\end{array}$ \\
\hline Sunflower Oil & 240 & $\mathrm{nl}$ & 405 & 31 & 20 \\
\hline Sunflower Oil & 240 & $\mathrm{nl}$ & 354 & 59 & 12 \\
\hline Corn Oil & 235 & $\mathrm{nl}$ & 156 & 749 & 28 \\
\hline Corn Oil & 240 & $\mathrm{nl}$ & 154 & 445 & 18 \\
\hline Olive Pomace Oil & 235 & 11 & 145 & 19 & 20 \\
\hline Olive Pomace Oil & 230 & 14 & 150 & 18 & 17 \\
\hline
\end{tabular}

affect the reduction of tocopherols in olive oil refining. The steam, the temperature and the preasure.The time has no significant influence. Steam and temperature are the most important.

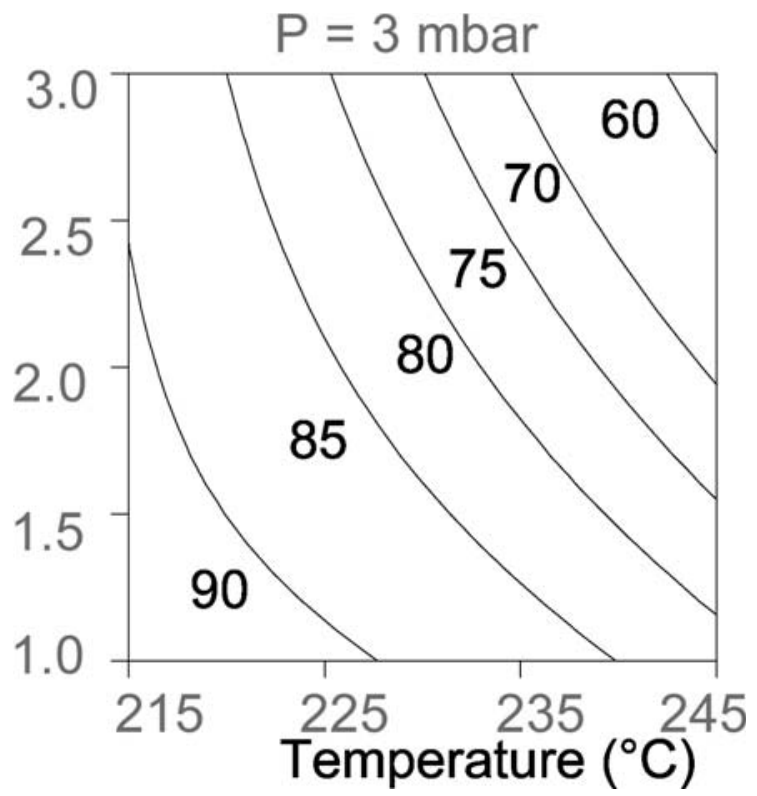

Figure 5

A tocopherol reduction during refining

\section{NEW TRENDS IN OLIVE OIL AND POMACE OIL REFINING}

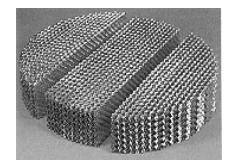

Figure 6

Packed Column Coating

The packed column technology is a new proposal from De Smet. The main adnantages of the technology are the high stripping efficiency and the low total steam consumption. The high contact oil vapour phase and the sort residence time are also strong points of the technique.

Latest Developments on Refining of Olive and Olive Kernel Oil are demanding increased interest and concern for the nutritional aspects of food oils and high sensitivity for the environmental issues. The only way is the improved deodorization technology and the research taking place in industries, Universities research institutes and European Union projects.

Physical Refining of Olive Oil using the advantages of stripping is the preferable technique for olive oil processing.

Light Refining of Olive Oil is a new idea from Alfa Laval Sweden in the same concept like the previous suggestions for low reduction of tocopherols.

Lampante olive oil reduces a lot of beneficial constitutes like extra virgin olive oil.

The increased stability of lampante olive oil can be attributed to the higher percentage of non saponificated fraction that has an antioxidant action. Moreover, from experiments that took place it was found that the crude oil had the greater stability and the discolored one the lower stability. Each stage of the refining removes certain components of the non saponificated fraction of the oil as well as preoxidant factors. The neutralization removes free fatty acids, phospholipids, metals and chlorophylls. The discoloration removes chlorophylls, carotenoids, peroxide, remaining free fatty acids and metals. However, during the discoloration conjugate dienes are simultaneously produced, which display higher oxidization rates. A light deodorization process, removing only odorous volatile compounds and free fatty acids, without any reduction of nutritional substances like sterols, tocopherols and polyphenols is the aim.

Changes in Sterol Composition (isomerism) during Olive Oil Processing is another parameter for optimising olive oil processing.

\section{DISTILATES AND THEIR COMMERCIAL VALUE}

The deodorizer distillate should be a blend obtained during deodorisation of different oils (mainly olive oil, but also corn oil, sunflower oil...). 
Basic quality parameters and the valuable minor components (tocopherols, sterols, squalene...) were analysed at De Smet Laboratory.

Light and Heavy Polycyclic Aromatic Hydrocarbons were analyzed at an external lab that is certified for this type of analyses.

\section{Observations}

- General composition of deodorizer distillate (FAD) shows quite high level of unsaponifiable matter $(32.45 \%)$.

- High level of squalene in the FAD (20.4\% table 2). Squalene is a poly-isoprenoïd $\mathrm{C}_{30}$ hydrocarbon that is present in relatively high amounts in olive oil (up to $0.5 \%$ ) which explains the high squalene concentration in the FAD.

- Squalene is known as a powerful antioxidant. It is marketed as a dietary supplement (mainly as major component of deep sea shark liver oils) with apparent positive effects aiganst cancer and beneficial effects on lowering blood pressure and cholesterol levels.

- FAD sample contains high levels of light Polycyclic Aromatic Hydrocarbons (16080 $\mathrm{ppb}=16,080 \mathrm{ppm}$ ) and lower levels of heavy $\mathrm{PAH}(250 \mathrm{ppb})$. Light PAH are removed during deodorisation. For this reason, it is not uncommon to detect elevated levels of light $\mathrm{PAH}$ in deodoriser distillates.

- The FAD may have some added value as source of squalene but only if the light and heavy $\mathrm{PAH}$ can be reduced (e.g. by a suitable adsorption process) to levels below $25 \mathrm{ppb}$ and $5 \mathrm{ppb}$, respectively. In relative terms this means that $99,85 \%$ of the light $\mathrm{PAH}$ and $98 \%$ of the heavy $\mathrm{PAH}$ have to be removed which requires a very efficient adsorption process.

\section{Detailed results}

Table 14

General composition of deodorizer distillate sample (origin MINERVA)

\begin{tabular}{lc}
\hline Parameters & FAD \\
\hline FFA $(\%$ C18:1) & 32.20 \\
\hline Unsaponifiable matter (\%) & 32.45 \\
\hline FAC (\%w/w) & \\
C 16:0 & 16.8 \\
C 16:1 & 0.7 \\
C 18: 0 & 2.7 \\
C 18:1 & 58.5 \\
C 18: 2 & 20.5 \\
C 18: 3 & 0.8 \\
\hline
\end{tabular}

Table 15

Detailed composition of the deodorizer distillate (direct GC analysis)

\begin{tabular}{ll}
\hline Component $(\% \mathbf{w} / \mathbf{w})$ & FAD \\
\hline FFA & 34.1 \\
\hline Squalene & $\mathbf{2 0 . 4}$ \\
\hline Monoglycerides & 4.4 \\
\hline Tocopherols & \\
$\alpha$-tocopherol & 1.0 \\
$\beta$-tocopherol & 0.3 \\
$\gamma$-tocopherol & 0.4 \\
Total & $\mathbf{1 . 7}$ \\
\hline Sterols & \\
campesterol & 0.2 \\
sitosterol & 2.3 \\
$\Delta-5$ avenasterol & 0.2 \\
$\Delta-7$ stigmasterol & 0.2 \\
$\Delta-7$ avenasterols & 0.4 \\
Total & $\mathbf{3 . 3}$ \\
\hline Diglycerides & 2.8 \\
\hline Triglycerides & 7.6 \\
\hline
\end{tabular}

Table 16

Detailed analysis of the PAH content of the deodorizer distillate

\begin{tabular}{lc}
\hline Component (ppb) & FAD \\
\hline Light PAH & \\
Benzo(a)anthracene & 540 \\
Anthracene & 350 \\
Chrysene & 1320 \\
Phenantrene & 5460 \\
Fluoranthene & 3590 \\
Pyrene & 3380 \\
Acenaphtalene & 1440 \\
Total light PAH & $\mathbf{1 6 0 8 0}$ \\
\hline Heavy PAH & \\
Benzo(a)pyrene & 40 \\
Benzo(b)fluoranthene & 120 \\
Benzo(k)fluoranthene & 90 \\
Total heavy PAH & $\mathbf{2 5 0}$ \\
\hline
\end{tabular}

\section{REFERENCES}

Christy, A. A., Kasemsumran, S., Du, Y., and Ozaki, Y. The Detection and Quantification of Adulteration in Olive Oil by Near-Infrared Spectroscopy and Chemometrics. Analytical Sciences (2004), 20, 935-940.

J.B.Rosell and J.L.R.Pritchard Analysis of Oilseeds, Fats and Fatty Foods, Elsevier Applied Science, 1991 (pp.451). 
Alfa-Laval: Methods of Analysis SWEDEN 1978.

Siragakis G, Falaras $P$ et al.Cottonseed oil bleaching by acid activated montmorillonite. Clay Minerals (1999) Vol 34 221-32.

E. Fedeli, N. Cortesi, and P. Rovellini. HPLC analysis for the detection of mixtures of high oleic seed oils with the olive oils. La Rivista Italiana delle Sostanze Grasse.Vol. 75. pp. 483-489 1998.

A Cert et al Chromatographic analysis of minor constituents in vegetable oils Journal of Chromatography. A 881(2000) 131-148.

S.Christoforaki, G.Siragakis, A.Spyros and P.Dais Detection of Refined and Lampante Olive Oil Adulteration in Virgin Olive Oils. J.Agric.Food Chem. 2005, 56 2780-2788.

T.Verleyen, U.Sosinka, S.loannidou, R.Verhe, K. Dewettinck, A.Huyghebaert and W.De Greyt.: Influence of the Vegetable Oil Refining Process on Free and Esterified Sterols JAOCS, Vol.79, no.10(2002).

Ian C. T. Nisbet, Peter K. Lagoy, 1992, Toxic Equivalency Factors (TEFs) for Polycyclic Aromatic Hydrocarbons
(PAHs). Regulatory Toxicology and Pharmacology, 16, 290-300.

Lanzón A. T. Albi, and A. Guinda. Formation of a D 7 triterpene alcohol in refined olive oils. Journal of the American Oil Chemists' Society 76 (1999) 14211424.

León Camacho, M., Ma.V. Ruiz-Méndez and E. Graciani Constante Changes in olive oil components during deodorization and/or physical refining at the pilot plant scale using nitrogen as stripping gas. Fett Lipid 101 (1999) 38-43.

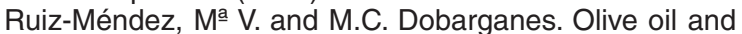
olive pomace oil refining. Oleagineux-Corp GrasLipides 6 (1999) 50-54.

George Siragakis, Youli Dimakou: NIR a new technique for on line monitoring olive oil quality First Greek Lipid Forum EIE June 2005, p O8.

Recibido: Septiembre 2005 Aceptado: Noviembre 2005 